\title{
Commercial Motorcycle Activity, Value Creation and the Environment in the Developing World: The Case of Nasarawa State, Nigeria
}

\author{
Ibrahim Gerarh UMARU (Corresponding author) \\ Department of Economics, Nasarawa State University \\ Keffi, Nigeria \\ E-mail: iumaru@yahoo.com
}

Received: July 21, 2013 Accepted: August 14, 2013 Published: August 31, 2013

doi:10.5296/ijssr.v1i1.4034

URL: http://dx.doi.org/10.5296/ijssr.v1i1.4034

\begin{abstract}
This study used a combination of survey techniques to examine the implications of the activity of commercial cyclists, popularly known as 'Achaba' (Hausa: motorized rickshaw) in Nasarawa state for the local economy, community and environment. The findings of the study show that apart from being a money spinner, this public transport mode has been making other modest contribution to the state's economy. The study also shows that this transport is a latent contributor to environmental degradation in the state for it might have degraded the environment in excess of \$6.98 million between 2006 and 2008. In addition, it is becoming a major source of road traffic morbidity and mortality. As policy measures, the study advocates for effective regulation of commercial motorcycle business in the state, imposition of appropriate environmental tax on users and operators and marshalling out a new transport policy with the aim of providing cheaper, efficient and environment-friendly urban mass transit.
\end{abstract}

Keywords: commercial motorcycle, environment, value creation, economic valuation, developing world, Nasarawa, Achaba

\section{Introduction}

The key element that connects the transport sector with the overall economy is mobility. Interestingly, mobility is one of the cardinal features of economic activity as it underlines the basic need of economic agents moving from one location to another - a need shared by critical factors in production, consumption and distribution spheres of the economy: 
passengers, freight and indeed information. Mobility is therefore an important and reliable indicator of development.

Generally, and especially in modern economy, the provision of mobility is an industry that offers services to customers, employs people, pays wages and salaries, invests capital and generates income. In fact, the economic importance of the transportation industry can be viewed from both macroeconomic and microeconomic perspectives. At the macroeconomic level, transportation and its component of mobility is connected to a level of output, employment and income within a national economy. In many countries, transportation accounts between 6 per cent and 12 per cent of the gross domestic products (GDP). In the case of Nigeria, it accounted for between 3.4 per cent and 5.9 per cent within the period, 1981-2003. (CBN, 2005) Transport is also a major activity in the informal non-manufacturing sector. A study estimated that about 150,794 establishments are in this business, creating about $\$ 4,250,328.33$ as total salaries and wages annually in Nigeria (CBN/FOS/NISER, 2001).

At the microeconomic level, transportation is linked to producer, consumer and production costs. The importance of specific transport activities can best be appreciated when assessed for each sector of the economy. It has been suggested that on a global scale, transportation accounts on the average between 10 per cent and 15 per cent of household expenditures, while at the same time representing about 4 per cent of the cost of each unit of output in manufacturing (Rodigue, 2007). Transport has equally played a catalytic role in major flows of national, regional and international migration, transforming the economic and social geography of many nations. For instance, transportation has been a tool of territorial control and exploitation in Nigeria, especially during the colonial era where resource-based transport systems (railways, inland waterways and roads) supported the extraction and evacuation of commodities from the hinterlands to major sea ports for export to the imperial metropoles (Hopkins, 1985; Olaloku, 1984; Akinwumi \& Umaru, 2006).

The evolution of transportation as an important factor in the economic development matrix of Nasarawa State, Nigeria presents an interesting story. Like in any other developing region of the country, the role of transportation in the development of the economy of the state cannot be overemphasized. This might not be far from the fact that when transport systems are efficient, they serve as bridgeheads to economic and social opportunities as well as benefits that have direct bearing on the social and economic development of the people (Fouracre et al., 1980; Fouracre et al., 1985; Nolan \& Lem, 2002). Transport as an important carriage of social and environmental load impacts on the economy through well-defined direct and indirect channels. Its direct impact relates to accessibility change where larger markets are enable to function efficiently through time savings. On the other hand, its indirect impact has to do with the economic multiplier effect, a situation where the prices of commodities drop and their varieties multiply.

Public transport in the state consists of a wide assortment of modes ranging from traditional man-powered rickshaws and animal drawn carts to the conventional taxis, buses and of recent origin commercial motorcycles, popularly referred to as "Achaba"(Hausa: motorized 
rickshaw). Since its inception as a separate geo-political entity in 1994, Nasarawa State has experienced rapid growth in the demand for public transport services due largely to urbanization, growth in population and economic activity. How this demand is being met and at what price, as well as estimating in quantitative terms, the contributions of this popular transport mode to the state economy and environmental degradation are the focus of this paper.

\section{Methodology}

\subsection{Scope}

Four towns were covered in this study namely, Lafia, Karu, Keffi and Akwanga (Figure 1). Interestingly, these towns are not only the leading urban settlements but operational headquarters for the commercial motorcycle business in the state.

\subsection{Data and Method}

The data used in this study were primary in nature, collected from cross-sectional surveys of motorcycle operators, officials of relevant trade unions and end users of their services. A combination of data collection techniques was used to collect the data. The questionnaire method (using stratified random sampling technique) was used to solicit data from end users/consumers. Similarly, using a simple random sampling technique, the interview approach was employed on commercial motorcycle operators. Lastly, focus group discussion (FGD) technique was used to collect data on membership, approved operational routes and time allowed, union due, local government taxes and garaging costs, official recorded accidents and other relevant information, from union officials.

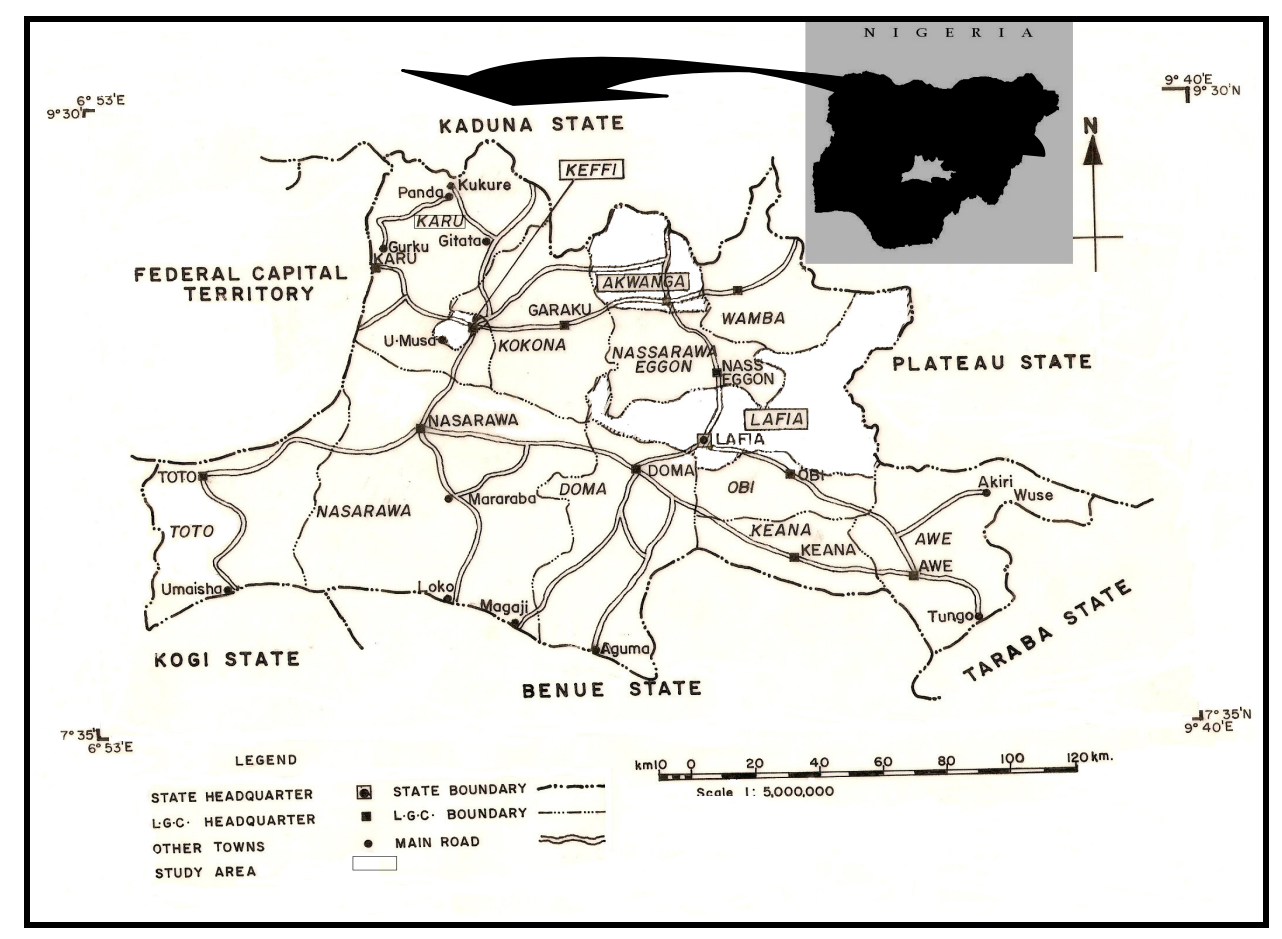

Figure 1. Location of Nasarawa state showing the study area 
Standard market valuation approach was used to estimate the economic implications of commercial motorcycle activity in Nasarawa State. In specific terms, data on daily average prices and quantities of commercial motorcycle services were used to arrive at annual estimates by assuming operators work 6 days, 4 times a month and 12 months in a year.

Incidence and number of accidents were used not only as proxy indices of the social implications, but as a basis for computing rough estimates of probable cost of mortality and morbidity in the study area due to urban air pollution arising from commercial motorcycle and other vehicular activities.

In computing the environmental cost implications (hidden effect) of commercial motorcycle activity in the state, the World Bank estimation criteria and assumptions [particularly the Disability Adjusted Life Year (DALY methodology)] were adopted. According to World Bank (2006), population weighted annual average fine suspended particulates less than 10 microns in diameter which are capable of penetrating deep into the respiratory tract of humans to cause damage (PM10) levels in major Nigeria cities and towns for the year 1999 were estimated between 93 and $114 \mu \mathrm{g} / \mathrm{m}^{3}$; but the Environmental Protection Agency (EPA) standards require this value to be below $50 \mu \mathrm{g} / \mathrm{m}^{3}$. Estimating the PM10 level is an important measure of health effect of air pollution as its coefficients are used as endpoints to determine the chronic obstructive pulmonary diseases (COPD) and lung cancer mortality, chronic bronchitis, restricted activity days, lower respiratory illness in children and respiratory symptoms. The report also indicates that epidemiology studies have shown that a $10 \mu \mathrm{g} / \mathrm{m}^{3}$ cut in PM10 reduces acute respiratory deaths by about 1 per cent. Finally, the report concludes that on the average 40,000 out of about 140 million Nigerians ( 0.0286 per cent $)$ die every year prematurely and 28,000 people ( 0.02 per cent) experience chronic bronchitis due to urban air pollution. We used these ratios as rough averages to estimate the potential annual morbidity and mortality due to urban air pollution in the four towns under study, using as basis the 2006 Census population figures.

Finally, figures were first computed in Nigeria's local currency, Naira ( $\$$ ) but later converted to US dollars (\$). The 2010 foreign exchange rate of Naira to US dollar was used as a basis. In 2010, \$1 exchanged for N152.25.

\section{Empirical Analysis}

\subsection{Socio-demographics}

Within the 3-year period of the study, a total of 1,129 operators were interviewed. Majority of them fall within the economically active age bracket, 18 - 65 years (Table 1).

A common feature of this public business is its free-entry-and-exit nature. The study also observed that not all operators were registered with the major commercial motorcycle unions; though membership attracts some welfare and operational benefits, it is legally speaking strictly optional. Table 1 shows the number, status and operational bases of operators in the four towns under study. 
Table 1. Socio-demographic Attributes of Commercial Motorcycle Operators in Nasarawa State (2006-2008 Averages)

\begin{tabular}{lcc|cc|cc|cc}
\hline & \multicolumn{8}{c}{ TOWNSHIP } \\
\cline { 2 - 10 } Category & \multicolumn{2}{c|}{ AKWANGA } & \multicolumn{2}{c}{ KARU } & \multicolumn{2}{c}{ KEFFI } & \multicolumn{2}{c}{ LAFIA } \\
\hline \multicolumn{1}{c}{ Age } & No. & $\mathbf{0}$ & No. & $\mathbf{0}$ & No. & $\mathbf{0}$ & No. & \% \\
\hline Below 18 & 57 & 15.6 & 82 & 24.4 & 107 & 27.4 & 96 & 27.6 \\
$18-39$ & 142 & 38.9 & 125 & 37.3 & 152 & 38.9 & 104 & 29.9 \\
$40-65$ & 139 & 38.1 & 96 & 28.7 & 107 & 27.4 & 95 & 27.3 \\
65 and above & 27 & 9.4 & 32 & 9.6 & 25 & 6.3 & 53 & 15.2 \\
\hline Total & $\mathbf{3 6 5}$ & $\mathbf{1 0 0}$ & $\mathbf{3 3 5}$ & $\mathbf{1 0 0}$ & $\mathbf{3 9 1}$ & $\mathbf{1 0 0}$ & $\mathbf{3 4 8}$ & $\mathbf{1 0 0}$ \\
\hline
\end{tabular}

Status and Number of Operators

\begin{tabular}{lccc|cc|cc|cc}
\hline \multicolumn{1}{c}{$\begin{array}{c}\text { Date of } \\
\text { estimate }\end{array}$} & $\begin{array}{c}\text { Reg'd } \\
*\end{array}$ & Unreg'd d & Reg'd & Unreg'd & Reg'd & Unreg'd & Reg'd & Unreg'd \\
\hline $\begin{array}{l}\text { As } \\
22 / 12 / 06\end{array}$ & at & 248 & 179 & 2,431 & 843 & 480 & 127 & 1,604 & 482 \\
$\begin{array}{l}\text { As } \\
19 / 10 / 07\end{array}$ & at & 721 & 302 & 3,879 & 1,241 & 1,082 & 128 & 3,339 & 746 \\
$\begin{array}{l}\text { As } \\
12 / 04 / 08\end{array}$ & at & 806 & 427 & 3,212 & 2,160 & 1,023 & 44 & 3,756 & 869 \\
\hline
\end{tabular}

Ownership Structure of Commercial Motorcycle ( $\%$ of Total)

\begin{tabular}{lc|c|c|c|c}
\hline Type & AKWANGA & KARU & KEFFI & LAFIA & Average \\
\hline Sole & 48 & 29 & 48 & 44 & $\mathbf{4 2 . 2 5}$ \\
Rental & 42 & 67 & 50 & 38 & $\mathbf{4 9 . 2 5}$ \\
Hire-purchase & 10 & 4 & 2 & 18 & $\mathbf{8 . 5}$ \\
\hline Total & $\mathbf{1 0 0}$ & $\mathbf{1 0 0}$ & $\mathbf{1 0 0}$ & $\mathbf{1 0 0}$ & $\mathbf{1 0 0}$ \\
\hline
\end{tabular}

Number of Years in Business

\begin{tabular}{cc|c|c|c}
\hline Year & AKWANGA & KARU & KEFFI & LAFIA \\
\hline$<1$ & 12 & 5 & 20 & 19 \\
$1-4$ & 20 & 32 & 24 & 17 \\
$5-9$ & 18 & 28 & 12 & 8 \\
$10-14$ & 25 & 12 & 23 & 8 \\
$15-19$ & 4 & 15 & 21 & 16 \\
$20-25$ & 15 & 5 & 0 & 25 \\
$>25$ & 6 & 3 & 0 & 15 \\
\hline Total & $\mathbf{1 0 0}$ & $\mathbf{1 0 0}$ & $\mathbf{1 0 0}$ & $\mathbf{1 0 0}$ \\
\hline
\end{tabular}

Educational Qualification

\begin{tabular}{lcc|cc|cc|cc}
\hline \multicolumn{2}{c}{ Level } & \multicolumn{2}{c|}{ AKWANGA } & \multicolumn{2}{c|}{ KARU } & \multicolumn{2}{c|}{ KEFFI } & \multicolumn{2}{c}{ LAFIA } \\
\hline Koranic & 24 & 6.6 & 4 & 1.2 & 35 & 9.0 & 12 & 3.5 \\
Primary & 164 & 44.9 & 135 & 40.3 & 124 & 31.7 & 189 & 54.3 \\
Secondary & 127 & 34.8 & 148 & 44.2 & 122 & 31.2 & 102 & 29.3 \\
Tertiary & 43 & 11.8 & 46 & 14.3 & 108 & 27.6 & 36 & 10.3 \\
None & 7 & 1.9 & 0 & 0 & 2 & 0.5 & 9 & 2.6 \\
\hline Total & $\mathbf{3 6 5}$ & $\mathbf{1 0 0}$ & $\mathbf{3 3 5}$ & $\mathbf{1 0 0}$ & $\mathbf{3 9 1}$ & $\mathbf{1 0 0}$ & $\mathbf{3 4 8}$ & $\mathbf{1 0 0}$ \\
\hline
\end{tabular}

Source: Authors' Survey (2006-2008).

* - Reg'd - Operators who claimed to be registered members of the major commercial motorcycle union in Nasarawa State, Nigeria.

\# Unreg'd - Operators who are registered with the major commercial motorcycle union in Nasarawa State, Nigeria. 
Other characteristics of operators, such as ownership structure, number of years in operation and educational qualification are shown in Table 1. To determine the sample size for the survey, we relied on the statistical formula suggested by Yamane (1973):

$$
n=\frac{N}{3+N(M E)^{2}}=\frac{828,976}{3+828,976(0.00064)} \approx 1,600
$$

where $n=$ desired sample size; $N=$ working population (total human population of the four local government areas in 2010, estimated from the 2006 national census figures (FRN, ) at 2.8 per cent the annual growth (NPC, 2002); $M E=$ margin of error allowable (2.5 per cent).

Out of a total number of 1,600 copies of questionnaire administered to customers as respondents, 1,439 were validly completed and returned. This represents an average total response rate of 89.94 per cent (Table 2). About $90 \%, 89 \%, 91 \%$ and $94.5 \%$ of respondents in Akwanga, Karu, Keffi and Lafia respectively indicated they use commercial motorcycle as their primary mode of public transport (Table 3).

Table 2. Socio-demographic attributes of respondents/customers (2006-2008 Averages)

\begin{tabular}{|c|c|c|c|c|c|c|c|c|}
\hline \multirow{2}{*}{$\begin{array}{l}\text { Respondent by } \\
\text { Gender }\end{array}$} & \multicolumn{2}{|c|}{ Questionnaire } & \multirow{2}{*}{\multicolumn{3}{|c|}{$\begin{array}{l}\text { Respondents } \\
\text { Gender }\end{array}$}} & \multicolumn{3}{|c|}{ Questionnaire } \\
\hline & No. & $\%$ & & & & & $\%$ & \\
\hline \multicolumn{3}{|c|}{ AKWANGA TOWNSHIP } & \multicolumn{6}{|c|}{ KEFFI TOWNSHIP } \\
\hline Female & 200 & 50 & \multicolumn{2}{|c|}{ Female } & \multicolumn{2}{|c|}{200} & \multicolumn{2}{|c|}{50} \\
\hline Response & 192 & 96.0 & \multicolumn{2}{|c|}{ Response } & \multicolumn{2}{|c|}{198} & \multicolumn{2}{|c|}{99} \\
\hline Male & 200 & 50 & \multicolumn{2}{|c|}{ Male } & \multicolumn{2}{|c|}{200} & \multicolumn{2}{|c|}{50} \\
\hline Response & 173 & 86.5 & \multicolumn{2}{|c|}{ Response } & \multicolumn{2}{|c|}{193} & \multicolumn{2}{|c|}{96.5} \\
\hline $\begin{array}{l}\text { Average } \\
\text { Response }\end{array}$ & & 91.25 & \multicolumn{4}{|c|}{$\begin{array}{l}\text { Average } \\
\text { Response }\end{array}$} & \multicolumn{2}{|c|}{97.75} \\
\hline \multicolumn{3}{|c|}{ KARU TOWNSHIP } & \multicolumn{6}{|c|}{ LAFIA TOWNSHIP } \\
\hline Female & 200 & 50 & \multicolumn{2}{|c|}{ Female } & \multicolumn{2}{|c|}{200} & \multicolumn{2}{|c|}{50} \\
\hline Response & 154 & 77 & \multicolumn{2}{|c|}{ Response } & \multicolumn{2}{|c|}{168} & \multicolumn{2}{|c|}{84} \\
\hline Male & 200 & 50 & \multicolumn{2}{|c|}{ Male } & \multicolumn{2}{|c|}{200} & \multicolumn{2}{|c|}{50} \\
\hline Response & 181 & 90.5 & \multicolumn{2}{|c|}{ Response } & \multicolumn{2}{|c|}{180} & & \\
\hline Average Response & & 83.75 & Ave & $\operatorname{Resp}$ & & & & \\
\hline & $\begin{array}{c}\text { Total } \\
\text { Total } \\
\text { Aver }\end{array}$ & $\begin{array}{l}\text { ber Ad } \\
\text { d Resp } \\
\text { Total R }\end{array}$ & $\begin{array}{l}\text { nister } \\
\text { se Ret } \\
\text { bonse }\end{array}$ & $\begin{array}{l}\text { ned } \\
\text { te }(\%)\end{array}$ & & $\begin{array}{l}1,600 \\
439 \\
.94\end{array}$ & & \\
\hline & AKV & $\overline{\mathrm{GA}}$ & & & & & & \\
\hline Occupation & TOM & & TOW & SHIP & тои & SHIP & тои & SHIP \\
\hline & No. & $\%$ & No. & $\%$ & No. & $\%$ & No. & $\%$ \\
\hline $\begin{array}{l}\text { Trading/ } \\
\text { business }\end{array}$ & 87 & 23.8 & 78 & 23.3 & 41 & 10.5 & 79 & 22.7 \\
\hline Civil service & 107 & 29.3 & 125 & 37.3 & 231 & 59.1 & 50 & 14.4 \\
\hline Student & 124 & 34.0 & 47 & 14.0 & 72 & 18.4 & 112 & 32.2 \\
\hline Applicant & 47 & 12.9 & 85 & 25.4 & 47 & 12.0 & 107 & 30.7 \\
\hline Total & 365 & 100 & 335 & 100 & 391 & 100 & 348 & 100 \\
\hline
\end{tabular}

Source: Author's Survey (2006-2008). 
As expected, majority of this number fall under the following occupational groups: traders, civil servants and students (Table 2).

Table 3. Yearly average number of respondents who patronize commercial motorcycle in Nasarawa state (2006-2008)

\begin{tabular}{lcccccccc}
\hline & \multicolumn{2}{c}{ AKWANGA } & \multicolumn{2}{c}{ KARU } & \multicolumn{2}{c}{ KEFFI } & \multicolumn{2}{c}{ LAFIA } \\
& \multicolumn{2}{c}{ TOWNSHIP } & \multicolumn{2}{c}{ TOWNSHIP } & \multicolumn{2}{c}{ TOWNSHIP } & \multicolumn{2}{c}{ TOWNSHIP } \\
Patronage & No. & $\mathbf{0}$ & No. & $\mathbf{0} \%$ & No. & $\mathbf{\%}$ & No. & \% \\
\hline $\begin{array}{l}\text { Use commercial } \\
\text { motorcycle }\end{array}$ & 329 & 90 & 298 & 89 & 356 & 91 & 329 & 94.5 \\
$\begin{array}{l}\text { Do not use commercial } \\
\text { motorcycle }\end{array}$ & 36 & 10 & 37 & 11 & 35 & 9 & 19 & 5.5 \\
\hline \multicolumn{1}{c}{ Total } & $\mathbf{3 6 5}$ & $\mathbf{1 0 0}$ & $\mathbf{3 3 5}$ & $\mathbf{1 0 0}$ & $\mathbf{3 9 1}$ & $\mathbf{1 0 0}$ & $\mathbf{3 4 8}$ & $\mathbf{1 0 0}$ \\
\hline
\end{tabular}

Source: Author's Survey (2006-2008).

\section{Economic Implications}

\subsection{User Costs}

Being an importance index of consumer revealed preference for existing modes of public transport, the average daily cost (in unit of time and money) of commercial motorcycle service in the selected four townships of Nasarawa state was estimated. In Lafia for example, a user pays an average of $\$ 0.24$ and uses 50 minutes to get to his workplace via motorcycle; he/she pays an average of $\$ 0.13$ and spends 30 minutes to get to the same places of work.

Table 4. User costs of commercial motorcycle service in Nasarawa state

\begin{tabular}{|c|c|c|c|c|c|}
\hline \multicolumn{3}{|c|}{ AKWANGA TOWNSHIP } & \multicolumn{3}{|c|}{ KEFFI TOWNSHIP } \\
\hline Mode & $\begin{array}{c}\text { Average } \\
\text { daily cost per } \\
\text { km (in } \\
\text { Minutes) }\end{array}$ & $\begin{array}{c}\text { Price per } \\
\text { km } \\
\text { (US \$) }\end{array}$ & Mode & $\begin{array}{c}\text { Average daily } \\
\text { cost per km } \\
\text { (in Minutes) }\end{array}$ & $\begin{array}{c}\text { Price per } \\
\text { km } \\
\text { (US \$) }\end{array}$ \\
\hline Walking & 63 & 0.80 & Walking & 60 & 0.69 \\
\hline Motorcycle & 27 & 0.13 & Motorcycle & 30 & 0.13 \\
\hline Bus/taxi & 38 & 0.21 & Bus/taxi & 42 & 0.20 \\
\hline $\begin{array}{l}\text { Personal } \\
\text { vehicle }\end{array}$ & 42 & 0.54 & $\begin{array}{l}\text { Personal } \\
\text { vehicle }\end{array}$ & 39 & 0.43 \\
\hline
\end{tabular}

\begin{tabular}{lcc|lcc}
\multicolumn{3}{c}{ KARU TOWNSHIP } & \multicolumn{3}{c}{ LAFIA TOWNSHIP } \\
\hline Mode & $\begin{array}{c}\text { Cost per km } \\
\text { (In Minutes) }\end{array}$ & $\begin{array}{c}\text { Price per } \\
\text { km (US \$) }\end{array}$ & Mode & $\begin{array}{r}\text { Cost per km } \\
\text { (In Minutes) }\end{array}$ & $\begin{array}{c}\text { Price per } \\
\text { km (US \$) }\end{array}$ \\
\hline Walking & 45 & 0.66 & Walking & 72 & 1.36 \\
Motorcycle & 20 & 0.16 & Motorcycle & 42 & 0.13 \\
Bus/taxi & 30 & 0.26 & Bus/taxi & 50 & 0.24 \\
$\begin{array}{l}\text { Personal } \\
\text { vehicle }\end{array}$ & 22 & 0.28 & Personal & & 0.46 \\
\hline
\end{tabular}

Source: Author's Survey (2006-2008). 
Similarly, a worker would rather pay an average of $\$ 0.16$ and 20 minutes via motorcycle than use 63 minutes and pay an equivalent of \$0.80. Similarly, the resident of Karu pays an average of $\$ 0.26$ and uses 38 minutes via bus/taxi to get to his/her workplace (Table 4).

The implication of all this is that, all things being equal, consumers tend to patronize commercial motorcycle as a cheaper and faster mode of public transportation when compared to others in the study area. This argument becomes even more tenable when a comparison is made of different modes with respect to the time and money saved as shown in Table 5.

Table 5. Time and money saved to workplace (2006 Estimates)

\begin{tabular}{lcccccc}
\hline & \multicolumn{2}{c}{$\begin{array}{c}\text { Using Motorcycle } \\
\text { rather than Walking }\end{array}$} & $\begin{array}{c}\text { Using Motorcycle } \\
\text { rather than Bus/taxi }\end{array}$ & $\begin{array}{c}\text { Using Motorcycle rather } \\
\text { than Personal Vehicle }\end{array}$ \\
\cline { 2 - 7 } Township & $\begin{array}{c}\text { In } \\
\text { Minutes }\end{array}$ & In US \$ & In Minutes & In US \$ & $\begin{array}{c}\text { In } \\
\text { Minutes }\end{array}$ & In US \$ \\
\hline Akwanga & 36 & 0.67 & 11 & 0.08 & 15 & 0.41 \\
Karu & 25 & 0.49 & 10 & 0.10 & 2 & 0.11 \\
Keffi & 30 & 0.56 & 12 & 0.07 & 9 & 0.30 \\
Lafia & 30 & 1.23 & 8 & 0.11 & 23 & 0.33 \\
\hline Average & $\mathbf{3 0 . 2 5}$ & 0.74 & $\mathbf{1 0 . 2 5}$ & 0.07 & $\mathbf{1 2 . 2 5}$ & 0.29 \\
\hline
\end{tabular}

Source: Author's Survey (2006-2008)

\subsection{Output Level}

The survey indicates that commercial motorcycle business in the study area enjoys huge patronage. While an annual average of 16,128 persons per operator used this mode in 2006, about 23,616 persons and 19,584 persons patronized the same mode in Akwanga in 2007 and 2008 , respectively.

The corresponding mean annual mileage per operator stood at $22,550.4 \mathrm{~km}, 15,753.6 \mathrm{~km}$ and $24,249.6 \mathrm{~km}$ for the same periods, respectively (Table 6). Similarly, Table 6 shows the mean annual number of passengers per operator and the mean annual mileage per operator for the remaining townships. 
Table 6. Output Level of commercial motorcycle business in Nasarawa state

\begin{tabular}{lcc}
\hline \multicolumn{3}{c}{ AKWANGA TOWNSHIP } \\
Year & $\begin{array}{c}\text { Mean No. of Passenger per annum per } \\
\text { operator }\end{array}$ & $\begin{array}{c}\text { Mean No. of km covered per annum } \\
\text { per operator }\end{array}$ \\
\hline 2006 & 16,128 & $22,550.4$ \\
2007 & 23,616 & $15,753.6$ \\
2008 & 19,584 & $24,249.6$ \\
\hline \multicolumn{3}{c}{ KARU TOWNSHIP } \\
Year & Mean No. of Passenger per annum per & Mean No. of km covered per annum \\
\hline 2006 & operator & per operator \\
2007 & 32,256 & 429,270 \\
2008 & 25,056 & $809,994.6$ \\
\hline \multicolumn{4}{c}{ KEFFI TOWNSHIP } \\
Year & 34,560 & $845,385.6$ \\
\hline 2006 & Mean No. of Passenger per annum per & Mean No. of km covered per annum \\
2007 & operator & per operator \\
2008 & 18,432 & $26,582.4$ \\
\hline \multicolumn{4}{c}{ LAFIA TOWNSHIP } \\
\hline \multicolumn{4}{c}{ Year } & 16,128 & $21,196.8$ \\
\hline 2006 & 16,704 & Mean No. of km covered per annum \\
2007 & per operator \\
2008 & Mean No. of Passenger per annum per & $210,709.2$ \\
\hline & operator & $501,469.5$ \\
\hline
\end{tabular}

Source: Authors' Survey (2006-2008).

\section{Notes:}

1. six (6) days in a week is assumed.

2. Mean no. of passenger per annum $=$ average passenger per day $\times 6$ days $\times 4$ weeks $\times 12$ months.

3. Mean no. of $\mathrm{km}$ covered per annum $=$ average daily distance covered by operator $\times 6$ days $\times 4$ weeks $\mathrm{x}$ 12 months.

\subsection{Revenue Generation}

The value of the annual turnover of commercial motorcycle in the four townships under study indicates that the commercial motorcycle business in Nasarawa State is a money spinner. Take for instance, in 2006 the business generated a mean total annual average of $\$ 31.62$ million [Akwanga (\$1.14 million); Karu (\$18.49 million); Keffi (\$1.66 million); and Lafia (\$10.33 million)]! The equivalent values for 2007 and 2008 are shown in Table 7 as $\$ 32.98$ million and $\$ 13.19$ million, respectively.

The ultimate goal for investors in commercial motorcycle business in Nasarawa State as elsewhere is to make profit. In recognition of this, the study estimated the average return on investment in 2006 based on computed cost and revenue structure in the four towns. Estimated all-operator profit for each of the four towns was \$982,121 (Akwanga); $\$ 5,005,290.38$ (Karu); \$621,989.57 (Keffi); and \$2,487,321.64 (Lafia). This translated to the following average profit per operator: \$2,216.98 (Akwanga); \$1,434.18 (Karu); \$1,358.06 (Keffi); and \$1,196.98 (Lafia) (Table 8). 
Table 7. Annual revenue of commercial motorcycle in Nasarawa state

\begin{tabular}{lcccccc}
\hline & \multicolumn{2}{c}{$\mathbf{2 0 0 6}$} & \multicolumn{2}{c}{$\mathbf{2 0 0 7}$} & \multicolumn{2}{c}{$\mathbf{2 0 0 8}^{*}$} \\
\cline { 2 - 7 } Township & $\begin{array}{c}\text { Mean } \\
\text { Annual } \\
\text { Revenue } \\
\text { per } \\
\text { Operator } \\
\text { (US\$) }\end{array}$ & $\begin{array}{c}\text { Mean Yearly } \\
\text { Total (US\$) }\end{array}$ & $\begin{array}{c}\text { Annual } \\
\text { Revenue } \\
\text { per }\end{array}$ & $\begin{array}{c}\text { Mean Yearly } \\
\text { Total (US\$) }\end{array}$ & $\begin{array}{c}\text { Annual } \\
\text { Revenue } \\
\text { per } \\
\text { Operator } \\
\text { (US\$) }\end{array}$ & $\begin{array}{c}\text { Mean Yearly } \\
\text { Total (US\$) } \\
\text { (US\$) }\end{array}$ \\
\hline Akwanga & $2,578.39$ & $1,142,227.13$ & 4,653 & $4,783,694.19$ & 575 & $800,725.12$ \\
Karu & $5,296.55$ & $18,484,965.52$ & 4,937 & $6,986,564.10$ & 6,810 & $5,604,508.37$ \\
Keffi & $3,631.92$ & $1,663,419.90$ & 3,178 & $3,340,005.52$ & 3,291 & $815,725.71$ \\
Lafia & $4,969.30$ & $10,326,206.42$ & 5,221 & $17,871,095.17$ & 7,718 & $5,920,863.84$ \\
\hline Total & & $\mathbf{3 1 , 6 1 6 , 8 1 8 . 9 7}$ & & $\mathbf{3 2 , 9 8 1 , 3 5 8 . 9 8}$ & & $\mathbf{1 3 , 1 4 1 , 8 2 3 . 0 5}$ \\
\hline
\end{tabular}

Source: Author's Survey (2006-2008).

Note:

* - Two months estimate (January - February).

1. Man annual revenue $=$ average daily price per $\mathrm{km} \times$ mean daily number of passengers per kilometer in the township.

2. Mean yearly total $=$ mean annual revenue per operator $x$ total number of operators in the township.

Table 8. The cost and revenue structure of commercial motorcycle in Nasarawa state (2006 Estimates)

\begin{tabular}{|c|c|c|c|c|}
\hline Revenue/Cost Item (US \$) & AKWANGA & KARU & KEFFI & LAFIA \\
\hline (a) Total Revenue (all Operators) & $1,142,227$ & $18,484,966$ & $2,017,652$ & $10,326.20$ \\
\hline Average Cost Price of Vehicle & 410.51 & 492.61 & 446.64 & 472.91 \\
\hline \multicolumn{5}{|l|}{ Fixed Cost per Operator } \\
\hline Licensing & 66 & 66 & 49 & 66 \\
\hline Union dues & 9 & 19 & 9 & 19 \\
\hline LG levy & 9 & 19 & 9 & 19 \\
\hline $\begin{array}{l}\text { Other (Tips, fines and penalties, } \\
\text { etc) }\end{array}$ & 76 & 123 & 47 & 66 \\
\hline Sub-total & 160.26 & 226.47 & 115.47 & 169.72 \\
\hline \multicolumn{5}{|l|}{ Operating Cost per Operator } \\
\hline $\begin{array}{l}\text { Depreciation ( } 25 \% \text { of cost price per } \\
\text { annum) }\end{array}$ & 102.63 & 123.15 & 111.66 & 118.23 \\
\hline Petrol & $1,284.41$ & $2,402.36$ & $1,346.84$ & $2,610.44$ \\
\hline Engine oil & 81.34 & 126.74 & 94.58 & 174.03 \\
\hline Repairs/maintenance & 794.48 & 983.65 & 605.32 & 699.90 \\
\hline Sub-Total & $2,262.86$ & $3,635.90$ & $2,158.40$ & $3,602.60$ \\
\hline Total Cost per Operator & $2,423.13$ & $3,862.37$ & $2,273.87$ & $3,772.32$ \\
\hline (b) Total Cost (all Operators) & $1,073,445.01$ & $13,479,675.14$ & $1,041,430.33$ & $7,838,884.78$ \\
\hline \multicolumn{5}{|l|}{ (c) Gross Profit (all Operators) } \\
\hline$[(a)-(b)]$ & $982,121.00$ & $5,005,290.38$ & $621,989.57$ & $2,487,321.64$ \\
\hline (d) Gross Profit per Operator* & $2,216.98$ & $1,434.18$ & $1,358.06$ & $1,196.98$ \\
\hline
\end{tabular}

Source: Author's Survey (2006-2008).

Notes:

* - Gross profit per operator $=$ gross profit (all operators) $\div$ total number of operators in the township. 


\section{Macrothink}

Aside from providing lucrative business avenue for private investors, commercial motorcycle activity serves as a means of mobilizing investible fund for economic growth and development as well as an avenue where the tall numbers of the unemployed can be cut down in the state. In 2006 alone, an estimated $\$ 83,799.01 ; \$ 990,266.01 ; \$ 86,633.83$ and $\$ 471.70$ were generated through personal savings in Akwanga, Karu, Keffi and Lafia townships respectively. By end of 2006, a total of $\$ 1,632,397.37$ had been generated as total personal savings within the study area (Figure 2).

As for employment, the number of persons employed in the sub-sector stood at 443; 3,490; 458; and 2,078 in Akwanga, Karu, Keffi and Lafia, respectively. In all, 6,469 were employed in the business in 2006. In 2007, the numbers increased by an average of 61.1 per cent; and by 2008 , the number stood at 12,273 persons (Table 9 ).

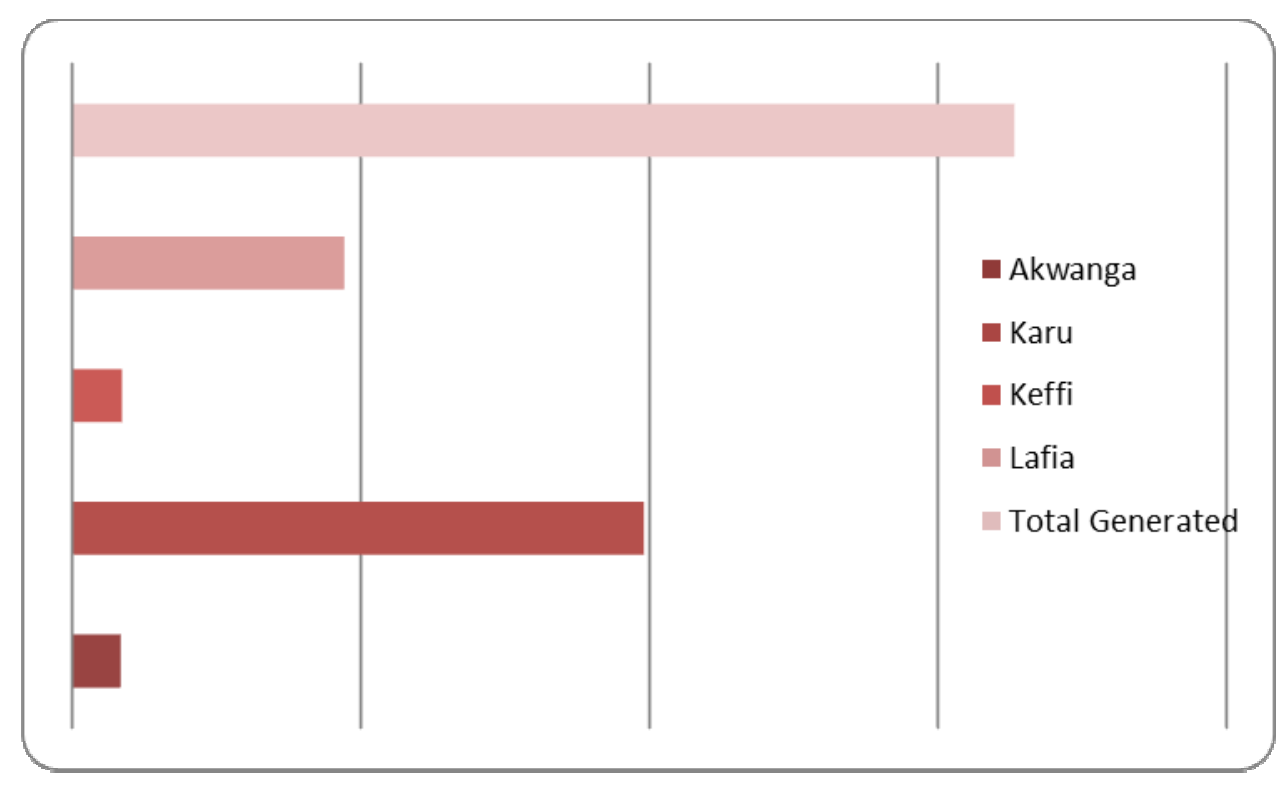

Figure 2. Commercial Motorcycle Operators’ Personal Savings ('000) per Annum, 2006 Estimates ('000)

Source: Author's Survey (2006-2008).

Notes:

* - Total personal savings $=$ average of N100 a day $\times$ days $\times 4$ weeks $\times 12$ months $\times$ average number of Operators in the township.

1. Personal savings through local 'adashi' or 'esusu' association.

Table 9. Employment Level in the Commercial Motorcycle Business in Nasarawa State 2006-2008 (Average)

\begin{tabular}{cccccc}
\hline & \multicolumn{5}{c}{ Mean Total Number of Operators } \\
\cline { 2 - 6 } Year & AKWANGA & KARU & KEFFI & LAFIA & Total \\
\hline 2006 & 443 & 3,490 & 458 & 2,078 & $\mathbf{6 , 4 6 9}$ \\
2007 & 1,028 & 4,918 & 1,051 & 3,423 & $\mathbf{1 0 , 4 2 0}$ \\
2008 & 1,245 & 4,938 & 1,487 & 4,603 & $\mathbf{1 2 , 2 7 3}$ \\
\hline
\end{tabular}

Source: Author's Survey (2006-2008). 


\subsection{Implications for Human Safety and the Environment}

How commercial motorcycle activity has been making positive contribution to the state economy should have been clear from the preceding analysis. Notwithstanding, the economic benefits bring in their trail some undesirable social and environmental effects, some of which are instantaneous in nature while others exhibit subtlety.

\subsection{Injury and Death-Related Effects}

Due to its relative disadvantages as a mechanical device, traffic accidents are generally a major risk associated with commercial motorcycle activity. The incidence of traffic accidents and the number of death are therefore good indices of such risk. To determine the incidence of accidents in the study area, operators were asked to indicate if they were ever involved in motorcycle traffic accident on duty. An average of 4.4 per cent of them indicated they did.

Table 10. Incidence of motorcycle traffic accident in Nasarawa state

\begin{tabular}{llllll}
\hline & \multicolumn{5}{c}{ Percentage } \\
\cline { 2 - 6 } Nature of Effect & AKWANGA & KARU & KEFFI & LAFIA & Average \\
\hline $\begin{array}{l}\text { Ratio of operators who were ever involved in } \\
\text { motorcycle traffic accident }\end{array}$ & 1.7 & 7 & 3 & 6 & $\mathbf{4 . 4}$ \\
$\begin{array}{l}\text { Ratio of operators who admitted they or their } \\
\text { passengers were injured in motorcycle traffic }\end{array}$ & 5.2 & 2.7 & 1.7 & 5.8 & $\mathbf{3 . 9}$ \\
$\begin{array}{l}\text { accident } \\
\begin{array}{l}\text { Ratio of operators who admitted that death } \\
\text { occurred during or after motorcycle traffic } \\
\text { accident }\end{array}\end{array}$ & 0.8 & 1.7 & 0.3 & 0.7 & $\mathbf{0 . 9}$ \\
\hline
\end{tabular}

Source: Author's Survey (2006-2008).

A follow-up question that tries to find out how many people sustain injury as a result of their activity reveals that about 4 per cent of those who admitted been involved in motorcycle accident between 2006 and 2008 revealed that at least one person was injured. When asked to indicate if death eventually resulted from such injuries, about 1 per cent answered in the affirmative (Table 10).

Furthermore, to gain insight into the likely cause of accidental mishap associated with commercial motorcycle activity, commuter-respondents were asked to identify the main cause of motorcycle accident in their locality. While an overwhelming 58.2 per cent identified reckless motoring/disregard of traffic codes, 15.6 per cent, 15.1 per cent and 11.1 per cent claimed bad road/weather condition, drunkenness/drug abuse and poor condition of vehicle, respectively (Table 11). 
Table 11. Main causes of motorcycle traffic accident in Nasarawa state

\begin{tabular}{|c|c|c|c|c|c|}
\hline \multirow[b]{2}{*}{ Cause } & \multicolumn{5}{|c|}{$\begin{array}{c}\text { Percentage of Respondents Who Indicated Positive } \\
\text { Answer }\end{array}$} \\
\hline & AKWANGA & KARU & KEFFI & LAFIA & Average \\
\hline Bad road/weather condition & 16.5 & 9.7 & 24.2 & 12.2 & 15.6 \\
\hline $\begin{array}{l}\text { Reckless riding/disregard of traffic codes } \\
\text { (rules) }\end{array}$ & 44.1 & 80.7 & 38.6 & 69.2 & 58.2 \\
\hline Poor condition of vehicle & 24.2 & 2.4 & 10.1 & 7.8 & 11.1 \\
\hline Drunkenness/drug abuse & 15.2 & 7.2 & 27.1 & 10.8 & 15.1 \\
\hline Total & 100 & 100 & 100 & 100 & 100 \\
\hline
\end{tabular}

Source: Author's Survey (2006-2008).

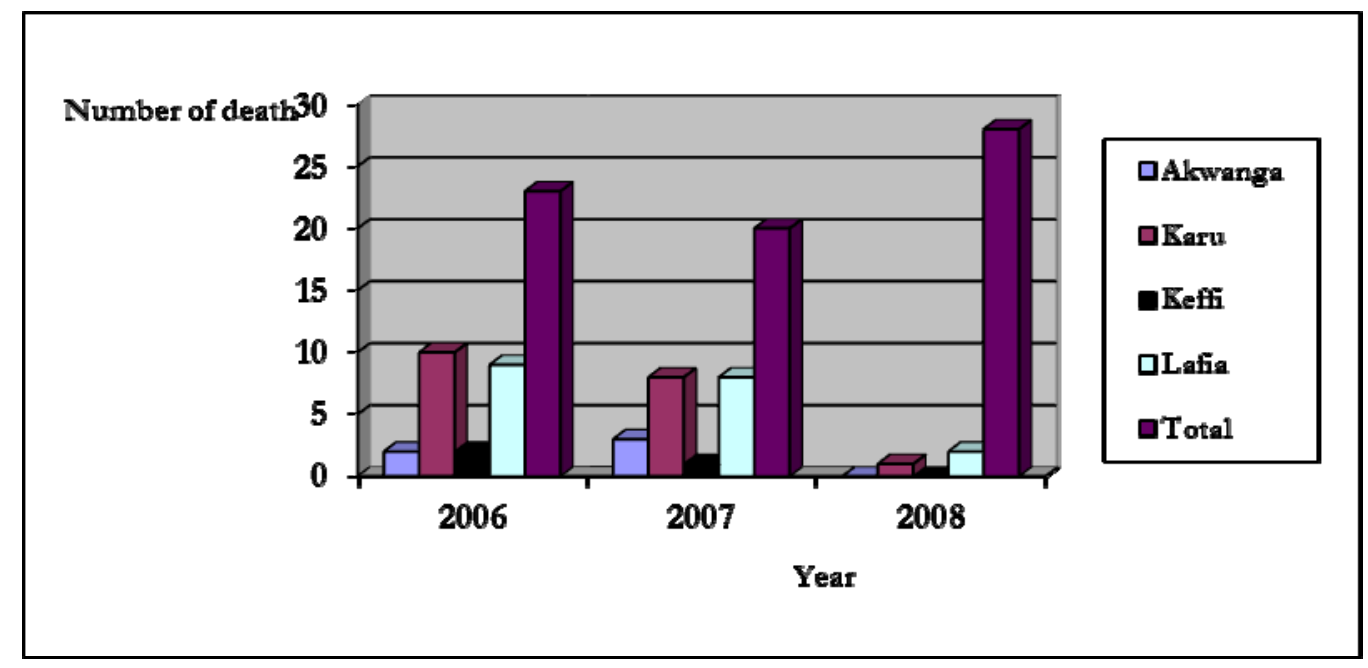

Figure 3. Number of Deaths from Motorcycle Traffic Accident in Nasarawa State

Source: Author's Survey (2006-2008).

From interviews with the branches of the major commercial motorcycle union in the study area, the number of deaths associated with commercial motorcycle activity was pieced together. In 2006 and 2007, about 23 persons and 20 persons died from motorcycle traffic accidents, respectively; while within the first two month of 2008, only 3 persons lost their lives (Figure 3).

\subsection{The Environment}

Accidents are direct negative consequences of commercial motorcycle activity, premature deaths and experiencing chronic respiratory problems are however the risks associated with air pollution which largely emanate from motorcycle and other automobiles in the urban areas. Attempt was made to estimate their potential effects on morbidity and mortality for the year 2006 in the study area. Table 12 indicates that out of a population of 113,430 , about 32 persons are liable to die prematurely while 23 persons may experience chronic respiratory problems in the future due to air pollution emanating from commercial motorcycle and other 
automobiles in Akwanga alone. Corresponding figures for Karu, Keffi and Lafia are 59 and 41; 27 and 19; and 95 and 66 persons, respectively.

Table 12. Potential Annual Morbidity and Mortality Due to Urban Air Pollution in Nasarawa State

\begin{tabular}{lcccc}
\hline & \multicolumn{3}{c}{ Township } \\
\cline { 2 - 5 } & AKWANGA & KARU & KEFFI & LAFIA \\
\cline { 2 - 5 } Population & 113,430 & 205,477 & 92,664 & 330,712 \\
Premature deaths & 32 & 59 & 27 & 95 \\
$\begin{array}{l}\text { Experience chronic respiratory } \\
\text { problems }^{*}\end{array}$ & 23 & 41 & 19 & 66 \\
\hline
\end{tabular}

Source: Calculations based on:

1. World Bank (2006: 67).

2. FRN (2007).

Notes:

* - Premature deaths $=$ population of township $\times 0.0286 \%$.

\# - experience chronic respiratory problems $=$ population of township $\times 0.02 \%$.

This health concern does not only portend unpalatable short- to medium term consequences for the host communities, but can be a monetary burden on the society in general as it is often associated with costs of illness, hospitalization, doctor visits and days lost to illness as well as care-giving. If we are therefore to use the World Bank (2006) standard of setting aside 0.53 percent of income or gross domestic product (GDP) as monetary value of environmental degradation of commercial motorcycle business in the study area, the total environmental cost per commercial motorcycle operators can be determined. Table 13 shows that the environmental cost of $\$ 264.83$ per operator in Karu town was the highest in 2006, while Lafia town generated the highest degradation in both 2007 and 2008 valued as \$261.04 and $\$ 64.32$, respectively.

Table 13. Estimated cost of environmental degradation from commercial motorcycle activity in Nasarawa state in US \$ $(2006-2008)^{\#}$

\begin{tabular}{|c|c|c|c|}
\hline \multirow[b]{2}{*}{ Revenue/Cost } & \multicolumn{3}{|c|}{ YEAR } \\
\hline & 2006 & 2007 & $2008^{*}$ \\
\hline \multicolumn{4}{|c|}{ AKWANGA } \\
\hline Gross revenue (GR) & $1,142,227.13$ & $4,783,694.19$ & $800,725.12$ \\
\hline $\begin{array}{l}\text { Total environmental cost for all operators } \\
\text { (TEC) }\end{array}$ & $57,111.36$ & $239,184.71$ & $40,036.26$ \\
\hline Environmental cost per operator (EC) & 128.92 & 232.67 & 32.16 \\
\hline \multicolumn{4}{|c|}{ KARU } \\
\hline Gross revenue (GR) & $18,484,965.52$ & $6,986,564.10$ & $5,604,508.37$ \\
\hline $\begin{array}{l}\text { Total environmental cost for all operators } \\
\text { (TEC) }\end{array}$ & $924,248.28$ & $3,493,282.05$ & $280,225.42$ \\
\hline Environmental cost per operator (EC) & 264.83 & 71.03 & 56.75 \\
\hline
\end{tabular}




\begin{tabular}{|c|c|c|c|}
\hline \multicolumn{4}{|c|}{ KEFFI } \\
\hline Gross revenue (GR) & $1,663,419.90$ & $3,340,005.52$ & $815,725.71$ \\
\hline $\begin{array}{l}\text { Total environmental cost for all operators } \\
\text { (TEC) }\end{array}$ & $83,171.00$ & $166,997.65$ & $40,786.29$ \\
\hline Environmental cost per operator (EC) & 181.60 & 158.90 & 27.43 \\
\hline \multicolumn{4}{|c|}{ LAFIA } \\
\hline Gross revenue (GR) & $10,326,206.42$ & $17,871,095.17$ & $5,920,863.84$ \\
\hline $\begin{array}{l}\text { Total environmental cost for all operators } \\
\text { (TEC) }\end{array}$ & $516,310.32$ & $893,554.76$ & $296,043.19$ \\
\hline Environmental cost per operator (EC) & 248.47 & 261.04 & 64.32 \\
\hline
\end{tabular}

Source: Author's Survey (2006-2008).

Notes

\# - The World Bank (2006) estimate of 5 per cent of GDP or income is used as basis.

* - Estimates for two months (January - February).
1. TEC $=$ GR $\times 5 / 100$;
2). $\mathrm{EC}=\mathrm{TEC} /$ Number of operators in the township.

If the environmental costs were to be internalized and expressed in the cost structure of commercial motorcycle business, its immediate net effect would be to demonstrate the real return on investment by deflating gross profit before tax per operators as shown in Table 14. Taking 2006 profit structure for the four towns as an illustration, the real return on investment for Akwanga and Lafia operators would have been $\$ 85.46$ and $\$ 948.51$ instead of $\$ 214.38$ and $\$ 1,196.98$ respectively; while for Karu and Keffi operators, it would have been $\$ 1,169.35$ and $\$ 1,176.46$ rather than $\$ 1,434.18$ and $\$ 1,196.98$ respectively.

Table 14. Net Effect of environmental degradation on profitability of commercial motorcycle business in Nasarawa state in US \$ (2006 Estimates)

\begin{tabular}{cccc}
\hline Township & $\begin{array}{c}\text { Gross Profit Before } \\
\text { Tax per Operator (a) }\end{array}$ & $\begin{array}{c}\text { Environmental Cost } \\
\text { per Operator }(\mathbf{b})\end{array}$ & $\begin{array}{c}\text { Net (Green) Return on } \\
\text { Investment }(\mathbf{c}=\mathbf{b}-\mathbf{a})\end{array}$ \\
\hline Akwanga & 214.38 & 128.92 & 85.46 \\
Karu & $1,434.18$ & 264.83 & $1,169.35$ \\
Keffi & $1,358.06$ & 181.60 & $1,176.46$ \\
Lafia & $1,196.98$ & 248.86 & 948.51 \\
\hline
\end{tabular}

Source: Author's Survey (2006-2008)

\section{Discussion}

From the findings of this study, a number of observations can be made of commercial motorcycle activity in Nasarawa State. One, it is a business that is characterized by free-entry-free-exit - there are hardly any tough restrictions on entry or exit to new entrants. This can be seen from the ratio of registered and unregistered operators in the four towns under study. 
Two, this public transport mode is indeed a highly lucrative venture. Aside from its characteristic high profitability with an average real (green) return rate of profit of over 200 per cent per annum, it is a multi-million dollar transport sub-sector judging by its impressive annual turnover. As a matter of fact, its annual average turnover is almost 10 per cent of the state's 2008 Budget (Table 9) (NSG, 2008). This makes it a huge potential source of revenue for the state government. However, the state and local government authorities seem to have neglected this huge source of revenue in preference for the monthly federal subventions coming from federal coffers.

Three, the commercial motorcycle business has been making steady contribution to the state's economy by way of providing jobs as well as helping to mobilize idle balances in form of personal savings. This investible pool of resources will remain idle unless the formal financial institutions in the state can effectively mobilize and re-channel them to productive sectors of economy where they most needed.

Four, commercial motorcycle activity in the state is not without its social costs. Incidents of traffic accidents and accident-related deaths are not only risks associated with business but regular occurrence on the urban streets in the state. The most worrisome aspect of accident is its long-term implication for the economy and society. Studies have shown that road traffic accidents affect the most productive groups of the population. In real terms, potential time (man hour) and resource are lost to grief and burial rites; potential savings lost to accident are incurred; tangible resources that otherwise would have been used to further production in the future are destroyed; sometimes even time and savings are recalled from investment and production for use in treating victims and permanent disability, while resources used for developing the perished human capital are lost forever (Umaru et al., 2011).

Last is the point that commercial motorcycle activity might have been contributing to environmental degradation in the state. An attempt to estimate cost of degradation to the urban areas under study indicated that $\$ 1,580,840.95$; $\$ 4,793,019.17$; and $\$ 657,091.15$ were generated 2006, 2007 and 2008 respectively as total environmental cost from commercial motorcycle business in the study area (Table 13). Despite these huge external costs to society, no attempt has been made by authorities to curtail or mitigate the problem through the imposition of environmental taxi on either the operators or the end users. This largely explains the growth in commercial motorcycle operators over the years, and its high rate of return on investment.

\section{Conclusion and Recommendations}

In sum, commercial motorcycle is about the most popular mode of public transportation in Nasarawa State, Nigeria. Aside from being a lucrative business, it has been making modest contribution in terms of employment, revenue generation and savings mobilization. Equally, it serves as an investment outlet. It is however associated with risks such as traffic accidents and accident-related deaths. It is yet a major contributor to environmental degradation in the state. 
Without doubt, if properly monitored and harnessed, commercial motorcycle business has the potential to even contribute more to the state's economy. However, for the state to get the best of it, adequate care must be taken to re-organize the business in order to minimize its capacity to degrade the environment. In line with this, the following policy options are recommended:

1) Using the appropriate organs, the state government should regulate the activities of commercial motorcycle and their unions in the state. Here the emphasis should be on licensing and route mapping;

2) A special department in the state Inland Board of Revenue (IBR) should be created and given the mandate to determine the appropriate tax system for the business, collect and remit personal and corporate taxes to the state coffers;

3) A special taskforce should be instituted in the state's vehicle inspection office (VIO) and empowered to enforce adherence to basic traffic codes such as the compulsory use of helmet, speed limits and routine vehicle inspection;

4) Appropriate willingness to pay (WTP) and/or willingness to accept (WTA) techniques should be used to determine appropriate user/operator costs so that the final price charged for commercial motorcycle services in the state would reflect their true (private plus external) values. A mechanism that would collect environmental taxes from users and operators should as well be put in place; and the proceeds accruing from such should go to a sinking fund that will be used to fund environmental policy intervention schemes; and

5) As a matter of urgency, the state government should articulate a new transport policy for the state which will prioritize mass urban commuting and make as ultimate goal of the policy the availability to the commuting public cheaper, more efficient and environment-friendly transit options.

\section{References}

Akinwumi, O., \& Umaru, I. (2006). History in Cash: A Study of Nigerian Currency (19502006). Faculty of Arts Monograph Series N0. 1, Nasarawa State University, Keffi-Nigeria.

CBN. (2005). Statistical Bulletin (pp. 212-214). Abuja: Central Bank of Nigeria.

CBN/FOS/NISER. (2001). A Study of Nigeria's Informal Sector Volume 1: Statistics on Nigeria's Informal Sector. Central Bank of Nigeria/Federal Office of Statistics/National Institute for Social and Economic Research, Abuja-Nigeria.

FRN. (2007). Federal Republic of Nigeria Official Gazette: Details of the Breakdown of the National and State Provisional Totals 2006 Census. Lagos: The Federal Government Printers.

Fouracre, P. R., Maunders, D. A. C., \& Jacobs, G. D. (1985). Public Transport Operations in Third World Cities. Crowthorne Baerkshire, United Kingdom: Overseas Unit, Transport and Road Research Laboratory. 


\section{Macrothink}

International Journal of Social Science Research

ISSN 2327-5510

2013, Vol. 1, No. 1

Fouracre, P. R., Maunders, D. A. C., Pathak, M. G. \& Rao, C. H. (1980). Public Transport Supply in Indian Cities. TRR1 Report LR 1018. Crowthorne Baerkshire, United Kingdom: Department of Environment; Department of Transport, 1980.

Hopkins, A. G. (1985). An Economic History of West Africa. Essex: Longman Group.

Jacobs, P., \& Vijayakumar, S. (1983). Factors affecting the use of public transport in cities in developed and developing countries. Traffic Engineering and Control, 24(5), 258-264.

Nasarawa State Government. (2008). Governor Akwe Doma signs 2008 budget. Retrieved from www.Nasarawastate.org/GovernorAkweDomaSigns2008Budget.htm

Noland, R. B., \& Lem, L. L. (2002). A review of the evidence for induced travel and changes in transportation and environmental policy in the US and the UK. Transport Research Part D: Transport and Environment, 7(1), 1-26. http://dx.doi.org/10.1016/S1361-9209(01)00009-8

NPC. (2002). Nigeria Population Census 1991 Analysis: National and State Population Projections. Abuja: United Nations Population Fund/National Population Commission.

Olaloku, F. A., Fajana, F. O., Tomori, S., \& Ukpong, I. I. (1984). Structure of the Nigerian Economy. Lagos: Macmillan publishers/ University of Lagos Press.

Rodigue, J. P. (2007). Transport and economic development. Retrieved December 30, 2007 from http://people.hofstra.edu/geotrans/eng/ch7en/conc7en/ch7c1en.html

Umaru, I. G., Uwaleke, U. J., \& Usman, A. (2010) Determinants of road traffic accidents in Nigeria: Simulation of the impact of policy options. Maiduguri Journal of Social and Management Studies, 2(1), 21-44.

World Bank. (1996). Poverty in the Midst of Plenty, the Challenge of Growth with Inclusion. Washington D.C: World Bank.

World Bank. (2006). Nigeria. Rapid Country Environmental Analysis (CEA). Environmental, Rural and Social Development (AFTS3), African Region. Document of the World Bank.

Yamane, T. (1973). Statistics: an Introductory Analysis. New York: Harper and Row.

\section{Copyright Disclaimer}

Copyright reserved by the author(s).

This article is an open-access article distributed under the terms and conditions of the Creative Commons Attribution license (http://creativecommons.org/licenses/by/3.0/). 